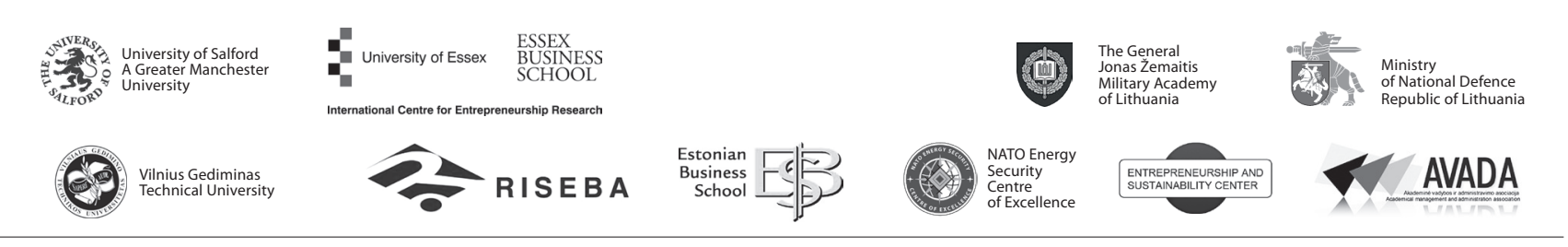

\author{
JOURNAL OF SECURITY AND SUSTAINABILITY ISSUES \\ ISSN 2029-7017 print/ISSN 2029-7025 online \\ 2018 June Volume 7 Number 4 \\ https://doi.org/10.9770/jssi.2018.7.4(14)
}

\title{
SUSTAINABLE DEVELOPMET PROCESSES: SERVICE SECTOR IN POST-INDUSTRIAL ECONOMY
}

\author{
Elena Petrenko ${ }^{1}$, Tatyana Pritvorova ${ }^{2}$, Baldyrgan Dzhazykbaeva ${ }^{3}$ \\ ${ }^{1}$ Plekhanov Russian University of Economic, 117997, Moscow, Stremyanny lane 36, Russia \\ ${ }^{2}$ E.A.Buketov Karaganda State University, 100026, Karaganda, str. Universitetskaya 28, Kazakhstan \\ ${ }^{3}$ Karaganda Economic University of Kazpotrebsoyuz, 100009, Karaganda, str. Academic 9, Kazakhstan \\ E-mails: ${ }^{1}$ petrenko_yelena@bk.ru, ${ }^{2}$ pritvorova_@mail.ru; ${ }^{3} m r . n a z a r o v i c h @ b k . r u$
}

\begin{abstract}
The article deals with the development of one of the service sectors, which is considered an element of the economic basis of the post-industrial development stage. The author considers the main indicators of the sector growth in the most competitive OECD countries, as well as compares the main macroeconomic structural and dynamic indicators of business and professional services in the USA and Kazakhstan, which made it possible to identify the main positions of Kazakhstan's lag. A comprehensive analysis of the dynamics and structure of the development of post-industrial services in Kazakhstan was carried out in all the significant parameters of the development of the types of services of this group that are available in domestic statistics. This made it possible to identify a group of development leaders; activities characterized by stability and a high market share, but weak dynamics; shrinking sectors. The negative trends in the development of the post-industrial services sector, determined as a result of the analysis and assessment, allow us to form a vision for further steps to develop them.
\end{abstract}

Keywords: post-industrial economy, business and professional services, analysis of dynamics and structure, assessment of the economic sector, Kazakhstan

Reference to this paper should be made as follows: Petrenko, E., Pritvorov, T., Dzhazykbaeba, B. 2018. Sustainable development processes: service sector in post-industrial economy, Journal of Security and Sustainability Issues 7(4): 781-791.

https://doi.org/10.9770/jssi.2018.7.4(14)

JEL Classifications: O15, O5, O53; P4; P47

\section{Introduction}

A fundamental economic theory that reveals the basic factors of the development of a modern highly productive economy is the theory of the post-industrial society, which considers scientific and technological progress and the accompanying scientific and technological revolutions to be the main driving force. The latest scientific and technological revolution is characterized by a radical increase in the importance of the service sector, with the specific role of information and communication services and scientific research in the development of society and improvement of its welfare. (Rostow 1973, Toffler 2010). In fact, this theory provides for the basis for the development of knowledge about the driving forces of the modern society, which in the form of national innovation systems, innovative clusters, interactive scientific and educational structures, network communities, and information and communication technologies determine the country's economic development and competitiveness in the modern world. (Bell 1986, Schwab, Porter, Sachs 2013).

A prominent feature of this complex system is the fact that it is largely based on high-quality services that 
determine the drivers of industrial production or are determined by them. The most significant structural shift that allows diagnosing entry into the post-industrial stage of the development is represented by the dynamic growth of business and professional services, which, being introduced into the production process at its initial or intermediate stage, have a decisive influence on the final product or the end result in the form of a service (Milner 2010; Balayeva, Predvoditeleva 2010; Dudzevičiūtè et al. 2014).

All industries and firms of the modern economy, without exception, include these science-intensive services (information and communication, scientific and technical, management and other types of consulting) in their business processes in order to ensure the competitiveness of their products and preserve it in the long term perspective(OECD Innovation and Knowledge-Intensive Service Activities. 2006). For Kazakhstan, which has set a goal to enter the top thirty of the most competitive countries in the world, one of the urgent tasks of the development is the structural reorganization of the economy and the implementation of the development programs aimed at the formation of the modern post-industrial structure of the economy (State program of industrial-innovative development, State program "Information Kazakhstan - 2020").

In scientific researches of the developed countries a significant array of studies are devoted to the development processes of services involving an intensive use of knowledge (e.g. Sarkar, Coelho, Maroco 2016; Zenka, Novotny, Slach, Ivan 2017; Zhou, Kautonen, Wang, 2017; (Tvaronavičiené, Shishkin 2017; Zemlickiene et al. 2017; Mura et al. 2017; Sulphey et al. 2018).

A review of the latest publications in the post-Soviet space shows that the issue of the development of the service sector in the mainstream of the modern techno-economic paradigm is paid attention to in the works of V. Inozemtsev , V. Varnavsky, L. Demidova , G. Vainstein , V. Kondratiev , F. Alzhanova , D. Ivanova and others(Bell, Inozemtsev 2007, Varnavsky 2016, Resp. editors Demidova, Kondratiev 2010, Demidova 2008, Vainstein 2012,Kondratiev 2011, Alzhanova 2016,Ivanov 2016). At the same time, the Kazakh science has not implemented yet the systematic statistical research of the basic parameters and indicators of the sphere of post-industrial services in its full extent.

The purpose of the research is to assess the development of the post-industrial services sector in Kazakhstan to identify negative and positive trends in the dynamics and structural shifts, including in comparison with the developed countries of the world.

Methods of the research. In the process of the research, statistical methods of processing economic data were used, in particular methods of grouping, analysis of dynamics and structure.

\section{Main results of the research}

Since the service sphere is extremely heterogeneous and has a distinct specificity in the provision of different types of services, the transition from the industrial to the post-industrial stage of the economy led to the refinement of classification by the leading researchers and the services are divided into the following groups:

1) distributive services are trade, transport, communication;

2) producer services are services for production, including both high-tech business and professional services, as well as services of a service character (administrative). This group also often includes financial, insurance, realtor services.

3) social services are services for society (educational, medical, social security) and public services;

4) personal services are individual services that are represented by art, accommodation and food services, recreational and entertainment services, all sorts of home services (Kastels 2000, Singelmann1978).

In our research, we used the OECD and NAICS classifications and the Kazakhstan methodology for the systematization of statistical data. 
In Europe, a special classification is also applied for services that use knowledge intensively, according to which they are divided into high-tech, financial, market-service, and others, including, among others, social services. This classification is based on the fact that knowledge and technologies based on it are applied in all types of services. For all its importance for countries that are only passing to the post-industrial stage of development, this classification is not quite appropriate, because many of these services are not scienceintensive(Classification of science-intensive services used in the OECD).

In our research we relied on classifications that were more suitable for cross-country comparisons and identified a group of services whose belonging to the science-intensive sector was unquestionable.

The general classification of services used by OECD distinguishes the following fairly large groups:

- distributive services (trade, transport, accommodation and food services);

- information and communication services;

- financial and insurance services;

- services related to real estate;

- professional, scientific and technical services; administrative services;

- public administration services, compulsory social services: education, health;

- other services(OECD site).

The new system of standard industry classification (NAICS - North American Industry Classification System) used in the USA and other countries in the region replaced in 1994 the outdated Standard Industrial Classification (SIC), which no longer reflected the specifics of the post-industrial stage.

Large groups in the new system are:

- wholesale trade;

- retail trade;

- transport and warehousing;

- information services;

- finance, insurance, real estate transactions;

- business and professional services;

- education, health, social welfare services;

- cultural and entertainment and leisure services, including accommodation and food services, recreation;

- other private sector services;

- public sector services, including education and health, social security (Information site of the Bureau of Economic Analysis of the USA).

In our research, we will refer two following groups to the post-industrial services, based on the generally accepted interpretation of the knowledge economy( Ed. by Kirichenko 2016).

1) business and professional services;

2) information and communication services.

\section{Trends in OECD countries.}

An assessment of the dynamics of the development of the service sector in the Eurozone and OECD countries that occupy the first positions in the global competitiveness ranking allows us to conclude that the average values for the Eurozone are significantly different from those of the leading countries. (Figure 1.) 


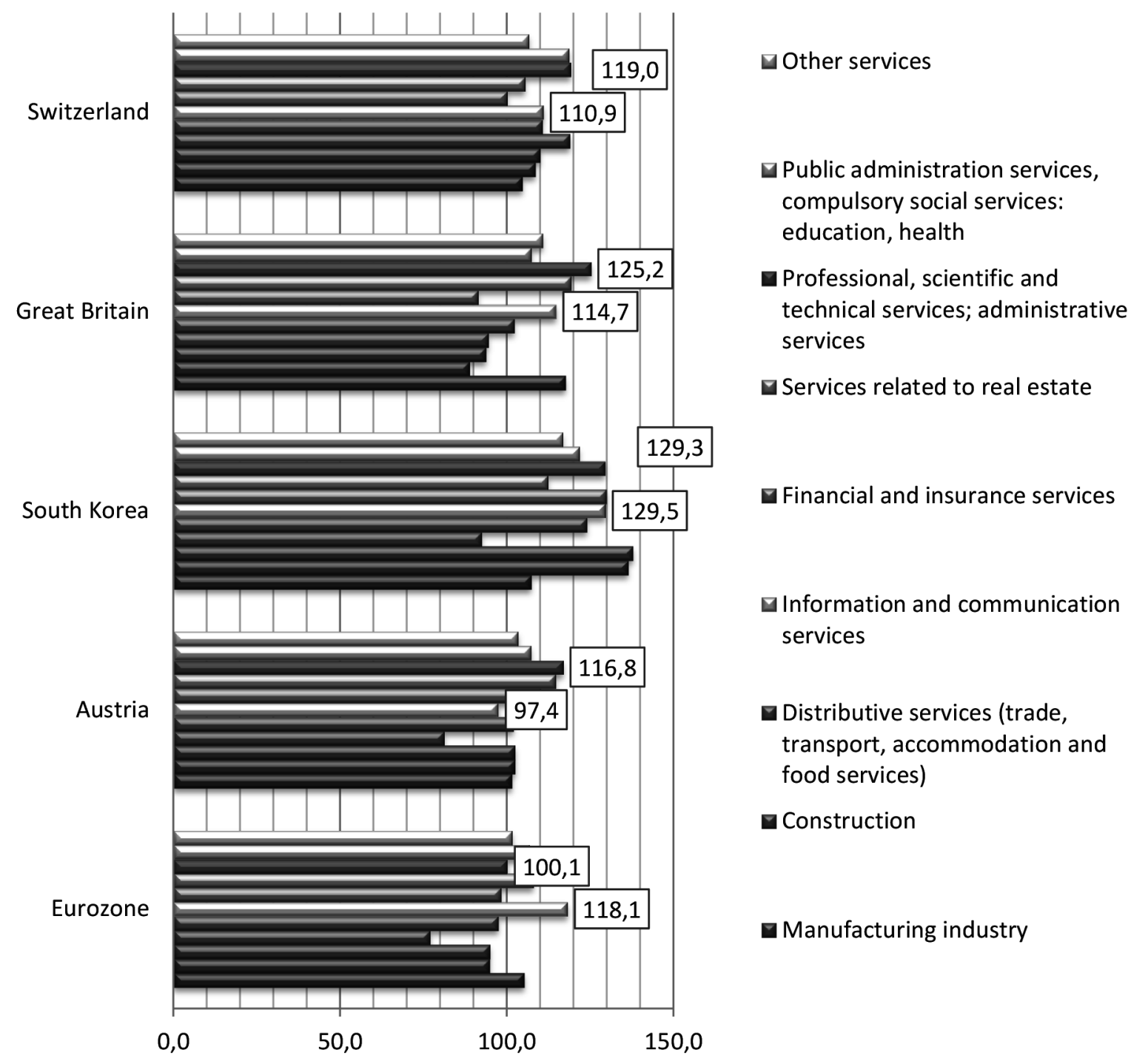

Fig 1. Rates of growth of economic activities in a number of OECD countries for 2016/2009 (in constant prices in 2012).

\author{
* Compiled by the author by the source \\ http://www.stat.gov.kz http://stat.gov.kz/faces/wcnav_externalId/classificatorsStat
}

Throughout the Eurozone, the leader of the economic growth over the period under consideration is communication and information services: the growth rate is $118.1 \%$, which is higher than in all other activities. Business and professional services have an increase of $100.1 \%$, which is generally lower than that of agriculture and financial services, but higher than in industry and construction. If to consider the most developed countries, then in these countries the growth rates of business and professional services certainly speak of their leadership. In Switzerland, Great Britain and Austria technical, scientific, and professional services are the leaders of the economic growth: $119 \%, 125.2 \%$, and $116.8 \%$, respectively. Information services in many countries are among the leaders in terms of the economic growth: Switzerland - $110.9 \%$, Great Britain - $114.7 \%$, France $-116.5 \%$. In South Korea, information and business services have grown almost the same: $129.5 \%$ and $129.3 \%$. South Korea is the only country, where industry is growing as intensively as business and professional services. 


\section{Trends in the USA.}

According to the share in GDP in 2016, business services rank third after financial and insurance activities (20.3\%), industry (15.4\%), business and professional services for business (11.1\%) (Table 1). For the period from 2012 to 2016 there is a growth trend in the aggregate GVA for the economy of the share of professional and business services by 0.3 percentage points and net profit for the household by 0.1 percentage points. During the period under consideration, there were positive structural shifts in the share of GVA and net profit for all types of services except for legal ones, whose share was reduced by $0.1 \%$. (The period was taken by us to ensure comparability of statistical data for the USA and Kazakhstan, since the latest data for Kazakhstan are presented for 2016 (http://www.stat.gov.kz).

The index of physical volume for business and professional services is $112.5 \%$ and is at the level of the average index for the production of services in the private sector, which has amounted to $112.8 \%$. In terms of the share of employment, business and professional services occupy the third place, and if to consider only the private sector, then the second one after a group of social services (education, health, social services). The share of employed in business professional services is $13.4 \%$ in 2016 , and $15.0 \%$ in the group of private social services.

Structural shifts in the US economy also took place in favor of business and professional services. In this sector for the period from 2012 to 2016, the largest increase in the structure of employment in the private sector of the economy was $0.5 \%$, the positive structural shift in business services was $0.5 \%$ and second only to construction. In fact, business and professional services in the USA during the period under consideration were one of the leaders in growth (together with financial services and construction) in terms of the share in gross output and the leader in employment growth. The trend of growth of social services (development of human capital) and business services (development of a high-tech economy with significant assets in scientific, technical, information and communication activities) is clearly revealed in the US economy.

\section{Trends in Kazakhstan.}

In the domestic structure of GDP, the position of business and professional services is currently rather modest. According to their share in 2016, they are on the $8^{\text {th }}$ place and this position has not changed since 2012. In Kazakhstan for the period from 2012 to 2016 there was a decrease in the share of professional and business services in GDP by $0.12 \%$ and an increase in employment in them by $0.4 \%$. The share in the aggregate GVA is $4.7 \%$, but there is a trend of growth in the specific weight by $0.6 \%$. There is also a trend of growth in net profit for the household by $0.7 \%$. The index of the physical volume of business and professional services amounted to $105.8 \%$, which is slightly lower than the average for services $-108.3 \%$. Drivers of growth of services in Kazakhstan are information and communication, art and entertainment, trade, accommodation and food services. The data of the comparative analysis for the USA and Kazakhstan are presented in Table 1. 
Table 1. Comparative analysis of basic indicators of the development of business and professional services in the US and Kazakhstan economy

\begin{tabular}{|c|c|c|}
\hline Comparison parameters & $\begin{array}{c}\text { USA* }^{*} \\
2012-2016\end{array}$ & $\begin{array}{c}\text { Kazakhstan } \\
\text { 2012-2016** }\end{array}$ \\
\hline $\begin{array}{l}\text { Share in GDP for the last year of the period, \%/ } \\
\text { Ranking among all activities, place }\end{array}$ & $\begin{array}{c}11.1 \\
3^{\text {rd }} \text { place }\end{array}$ & $\begin{array}{c}4.3 \\
8^{\text {th }} \text { place }\end{array}$ \\
\hline Structural shift in the share in GDP, \% & 0.5 & -0.12 \\
\hline $\begin{array}{l}\text { Share in employment for the last year of the period, \%/ } \\
\text { Ranking among all activities, place }\end{array}$ & $\begin{array}{l}13.4 \% \\
3^{\text {rd }} \text { place }\end{array}$ & $\begin{array}{c}2.6 \% \\
11^{\text {th }} \text { place }\end{array}$ \\
\hline Structural shift in employment share, $\%$ & 0.5 & 0.4 \\
\hline $\begin{array}{l}\text { Index of physical volume for the period, } \% \text { / } \\
\text { Similar index for all services, } \%\end{array}$ & $\begin{array}{l}112.5 \\
112.8\end{array}$ & $\begin{array}{l}105.8 \\
108.3\end{array}$ \\
\hline Share in total GVA for household for the last year of the period, $\% /$ Structural shift, $\%$ & $12.2 / 0.3$ & $4.7 / 0.6$ \\
\hline Share in total net profit for household for the last year of the period, $\%$ / Structural shift, $\%$ & $7.6 / 0.1$ & $3.6 / 0.7$ \\
\hline $\begin{array}{l}* \text { Data source https://www.bea.gov/national/index.htm } \\
* * \text { Data source http://www.stat.gov.kz }\end{array}$ & & \\
\hline
\end{tabular}

\section{Main indicators of dynamics and structure of post-industrial services in Kazakhstan for 2012-2016.}

Based on the interpretation of post-industrial services, which we outlined in the theoretical chapter, we refer to this type of services a number of services, whose full name, according to the basic classifier adopted in Kazakhstan, is as follows:

- computer programming services, consulting and similar services;

- information services;

- legal and accounting services;

- services of parent companies; consulting services on management issues;

- services in the field of architecture, engineering surveys, technical testing and analysis;

- research and development services;

- services in the field of advertising and market research;

- professional, scientific and technical services (http://www.stat.gov.kz ).

Based on the aggregate indicators of the index of the physical volume of services rendered, the share in the structure of the production volumes of the services sector and the average annual growth rate of the number of organizations, we provided a qualitative assessment of the development of each type of services and they are grouped according to the development trends. (Table 2)

Leadership sector includes scientific and technical services, consulting services on management issues, information services and computer programming services. They demonstrate a growing index of the physical volume above the average in the service sector and an increase in the share in the structure of the production volumes of services. The first two types of services are characterized by enlarging the volume of activity and eliminating noncompetitive organizations. The sector, which includes services in the field of architecture, engineering and technical testing and analysis, legal and accounting services is characterized by a high accumulated share of production in the services sector, stable production volumes, with no growth during the period under consideration, and some reduction in the structural share. The number of organizations also does not increase or decrease. In this regard, we described it as the "stability without growth". The shrinking sector includes services in the field of advertising and market research and research and development services. These types of services are characterized by a reduction in the production volumes, respectively, a reduction in structural shares and the number of organizations. The aggregate of post-industrial services clearly shows the trend of decreasing the share of medium-sized enterprises in the production volumes in favor of either large or small firms. In the leadership group, a clear shift in favor of large enterprises with a decrease in the share of medium and small ones is observed in scientific and technical and information services. Obviously, for leaders, large forms 
are more competitive, because the type of activity is capital-intensive and such firms have greater opportunities. For other activities, as in legal and accounting services, optimization is in the direction of reducing the size.

Table 2. The main indicators of the development of post-industrial services, 2012-2016

\begin{tabular}{|c|c|c|c|}
\hline Types of services & $\begin{array}{l}\text { Index of the physical } \\
\text { volume of services } \\
\text { rendered, } \%\end{array}$ & $\begin{array}{l}\text { Change in the share in } \\
\text { the structure of the pro- } \\
\text { duction volumes in the } \\
\text { service industry, } \%\end{array}$ & $\begin{array}{l}\text { Average annual growth } \\
\text { rate of the number } \\
\text { of organizations, } \%\end{array}$ \\
\hline \multicolumn{4}{|c|}{ Leadership sector } \\
\hline Professional, scientific and technical services & 118.9 & 1.6 & 99 \\
\hline Consulting services on management issues & 111 & 1 & 96 \\
\hline Information services & 109.1 & 0.2 & 107 \\
\hline Computer programming services & 107.2 & 0.4 & 109 \\
\hline \multicolumn{4}{|c|}{ The sector of organizations with a high accumulated structural share, but without dynamics (stability without growth) } \\
\hline $\begin{array}{l}\text { Services in the field of architecture, engineering and } \\
\text { technical testing, analysis }\end{array}$ & 101.6 & -3.1 & 100 \\
\hline Legal and accounting services & & & 100 \\
\hline \multicolumn{4}{|c|}{ Shrinking sector } \\
\hline Services in the field of advertising and market research & 98.5 & -1.3 & 95 \\
\hline Research and development services & 96.7 & -0.8 & 97 \\
\hline
\end{tabular}

A characteristic feature of the post-industrial services sector in Kazakhstan is that the share of foreign ownership makes up a significant number $-27.2 \%$, and in five types of services it is close to $30 \%$ or more.

In 2016, foreign ownership in the leading activities is most significantly represented in:

- professional, scientific and technical services - $28.0 \%$;

- consulting services on management issues - $30.2 \%$;

- computer programming services $-24.5 \%$.

Industries with a high accumulated share in the services sector are also characterized by the active participation of foreign ownership in the production volumes:

- services in the field of architecture, engineering surveys, technical testing and analysis $-37 \%$;

- legal and accounting services $-44.6 \%$.

At the same time, on average in the service sector (except for education, health, social security and public administration), foreign ownership is $15.9 \%$ this year.

\section{Characteristics of individual segments of post-industrial services and their types in 2016.}

In computer services, $50 \%$ of the supply on the domestic market is occupied by services for developing application programs. As a result, the segment's development trend can be recognized as intellectual, because this type of activity requires a high level of professional training and qualifications.

In the segment of information services, the leadership belongs to the service on the "provision of infrastructure for data and IT-technologies placement" (39.4\%), which is not an intellectual trend in the development of information services; it is the exploitation of a variety of technical means for the production of information services. While the processing of sites in the Internet and the maintenance of the Internet portals can be considered services with a higher intellectual component, they grow more intensively than the segment as a whole, but the share of these services is still very small $-3.8 \%$ and $4.9 \%$, respectively, although in five years they increased by $1 \%$ and $2.3 \%$, respectively. 
Management consulting in terms of production volumes ranks second in the group of post-industrial services after architectural, engineering and technical services both in 2012 and in 2016 . The sector's dynamics (142\% of growth) is also one of the highest, for example, it exceeds the rapidly growing computer services ( $116 \%$ over the same period). At the same time, the growth rates of different types of services are significantly uneven. The growth leader is the services of logistics, chain stands and other managements, which currently occupy $48.9 \%$ of the market and grew by $1073 \%$ over the period. The second on demand are services of strategic management, production management, project management (except for construction projects). In the group of services with negative growth rates, marketing services, public relations services, and services for creating trademarks fell. In connection with the above-described trends, market diversification has declined; market concentration on logistics services and other management issues has increased. To maintain the share of its market niche, it was only possible to consult on strategic management issues, which takes $16.6 \%$ of the market in 2016 , while in 2012 it was at the level of $17.1 \%$.

Services in the field of architecture, engineering surveys, technical testing and analysis represent the most significant segment of the domestic market of post-industrial services. The dominant type of services in terms of their share in this segment are geological and geophysical services, which generally corresponds to the outstripping growth rates of the mining industry in Kazakhstan's economy. This group includes services for exploration and evaluation of minerals, ground surveying services, mapping services. The second place in this market was occupied by architectural services of all kinds, which are the leader with growth rates of $82.5 \%$, which is higher than in the whole segment (38.5\%). The share of the market for this type of services was $27.9 \%$ in 2016 , an increase of $6.8 \%$ as compared to 2012. Engineering services moved from the second to the third place, which is due to the sluggish development of the manufacturing industry in the country as a whole. In legal and accounting services, during the period under consideration, a permanent four is allocated: other legal services, civil law services, financial audit services, accounting services. These four positions, with some variation in specific gravity, retain their leadership in the market. There is practically no horizontal diversification of services in this segment of the market. In the field of scientific research and development, the leaders are natural sciences (the share is 52.8\%) and developments in the field of techniques and technology, but incommensurably less $-9.5 \%$. Absolute growth leaders are research and development in the field of nanotechnology and medicine, but their specific weights in 2016 are small $(0.6 \%$ and 3.2\%). Services in the field of advertising and market research reflect the crisis trends in the economy of Kazakhstan, when only basic advertising products are in demand, the share of which has decreased from $84.1 \%$ to $82.2 \%$. At the same time, services for in-depth market research have grown to $1.9 \%$. In the group of professional, scientific and technical services, services, which are not included in other groupings (47.9\%) and scientific and technical consulting (40.5\%), which is almost 4 times higher than the average segment, dominate.

\section{Discussion}

Evaluation of the development of the post-industrial services sector in Kazakhstan makes it possible to determine its role in the economy of the country as rather modest. In terms of share in GDP, the sector ranks $8^{\text {th }}$, having negative dynamics of the structural shift, over the past five years by 0.12 positions. On employment in the sector there is a positive structural shift of 0.4 positions at the $11^{\text {th }}$ place in the 2016 ranking. The index of the physical volume has a lower value than the service sector as a whole. Positive trends are the growth of the share in the aggregate GVA (by $0.6 \%$ ) and net profit for the household as a whole (by $0.7 \%$ ).

Comparison with the values of similar indicators of the development of the post-industrial services sector in the United States makes it possible to estimate the distance between the most competitive developed countries that have middle and high-tech frames as a core of the economy, and Kazakhstan, which aspires to enter the top thirty of the developed countries in the world.

A positive sign of this movement is the presence of scientific and technical consulting, consulting on management issues, and computer programming services among the leaders of the sector of post-industrial services. The main food items, according to which the domestic supply in these markets is developing, can be recognized 
as intellectual, requiring high professionalism and qualification. These services include the development of application programs in the computer services market; logistics services, strategic management services, production management services, project management in the market of management consulting; services of scientific and technical consulting in the domestic segment of professional and scientific and technical services.

The evidence that there is a strong competitive struggle in the markets is that medium-sized firms leave the market, growing to large (information, scientific and technical services) or optimizing to small (legal, accounting, advertising and market research services) in different segments of the market.

The most successful types of post-industrial services in their development are characterized by the significant participation of foreign ownership. In post-industrial services, foreign ownership is represented by a significant share $-27.2 \%$ against $15.9 \%$ on average in the sphere. The share of foreign ownership in the field of architecture, engineering and technical testing, analysis is $37 \%$ (while the share of this type of services is $39.8 \%$ of the total production volume in the post-industrial services sector in 2016); the share in management consulting is $30.2 \%$ (with the share in the sector of $13.8 \%$ and the second place in the importance of the type of activity). In general, this shows the main trend of the sector - the transfer of best practices and the desire to increase the competitiveness of domestic firms due to their localization in Kazakhstan.

Negative trends reflecting the problems of structural adjustment of the economy, or rather of its absence for the period from 2012 to 2016 include the following phenomena. The dominant activities in the services in the field of architecture, technical and engineering testing are geology and geophysics services (34.2\% of the segment), which generally corresponds to the outstripping growth of the mining industry in Kazakhstan's economy. This group includes services for exploration and evaluation of minerals, ground surveying services, mapping services. The absence of a pronounced dynamics in the development of manufacturing industry was reflected in the shift in engineering services from the second to the third place, and the technical tests and analysis for the fourth one. Now services of architecture of all kinds are ahead by the market share. The most negative trend is the reduction of all the basic indicators in research and development services and, in fact, the last place of this activity among all the post-industrial services.

\section{Conclusions}

The leading dynamics of the post-industrial services sector in the most competitive OECD countries (Switzerland, Great Britain, Austria, South Korea and others) is one of the characteristics of their economies, which determine not only the post-industrial quality of development, but also leadership in the world arena. An elementwise comparison of the main indicators of the dynamics and structure of the development of post-industrial services in the USA and Kazakhstan allows us to compare the role of business and professional services in the economies of these countries. If in the USA this group of services has the third place in terms of its share in GDP and its share in employment, i.e. along with the financial sector and industry it is the driver of the growth, in Kazakhstan this sector is on the second, and for some services on the third place.

The negative structural shift in the GDP of Kazakhstan in the business and professional services sector for the period from 2012 to 2016 indicates a relative shrinking in its development. Positive trends are an increase in its participation in the aggregate GVA and net profit for the household. This indicates complex and contradictory trends within the sector. Positive trends include a steady growth in the volume of computer programming services provided (in all regions) and management consulting services (in 10 out of 16 regions).

On the one hand, over the past five years, there has been an increase in the foreign presence in the provision of post-industrial services, the mastery of effective technologies and practices for their provision. Foreign participation is a significant factor in the development of architectural services, engineering surveys, technical testing and analysis, scientific and technical consulting, strategic management and logistics. The absence of a critical mass of structural restructuring of the economy as a whole, causes the dominance of services related to geological and geophysical research, while engineering surveys and technical tests have lost their positions in the last 
five years. The most negative trend is the reduction of all the economic indicators of research and development services. Despite the presence of dynamics in the indicators of natural sciences, nanotechnology and medical research, their positions do not yet provide grounds for talking about a turning point in the scientific sphere and do not affect the main economic indicators. Thus, the main factors of the growth of the post-industrial services sector - the manufacturing industry and science - do not yet give grounds for talking about a directed movement toward the post-industrial economy. Factors of such movement should be structural reorganization and development of scientific research in the natural and technical fields.

\section{References}

Alzhanova, F.G. 2016. The formation of a science-intensive economy and the dynamics of the scientific potential of Kazakhstan/ Collection of articles on the materials of the LIV International Scientific and Practical Conference "Scientific discussion: innovations in the modern world". 10(53): 39-44.

Balayeva, A.; Predvoditeleva, M. 2017. Services sphere in the World Economy: Development Trends, World economy and international relations 2(3), p. 23.

Bell D.; Inozemtsev, V.L. 2007. The Epoch of Disunity: Reflections on the World of the $21^{\text {st }}$ century. Moscow: Free thought: Center for Post-Industrial Society Studies, 303 p.

Bell, D. 1986. Social frame of the information society, a new technocratic wave in the West. Moscow: Progress, p. $330-342$.

Classification of science-intensive services used in the OECD. http://ec.europa.eu/eurostat/statistics-explained/index.php/ Glossary:Knowledge-intensive_services_(KIS)

Demidova, L. 2008. Russia's Services Sector: A Difficult Way to Modernize, World economy and international relations 2: 38-50.

Dudzevičiūtè, G. Mačiulis, A.; Tvaronavičienė, M.. 2014. Structural changes of economies: Lithuania in the global context, Technological and economic development of economy 20(2): 353-370. http://dx.doi.org/10.3846/20294913.2014.915597

Information site of the Bureau of Economic Analysis of the USA. http://www.bea.gov/

Information site of the Committee on Statistics of the Ministry of National Economy of the Republic of Kazakhstan. http://www.stat. gov.kz http://stat.gov.kz/faces/wcnav_externalId/classificatorsStat

Innovative development: economy, intellectual resources, knowledge management/ Edited by B.Milner. M.:INFRA-M, 2010. - 624 p.

Ivanov, D. 2016. Human Capital and Knowledge-Intensive Industries Location: Evidence from Soviet Legacy in Russia, Journal of Economic History 76(3): 736-768.

Kastels, M. 2000. Information era: economy, society, culture. M.: Higher School of Economics, 608 p

Kondratiev, V.B. 2011. Services in the postindustrial economy, Creative economy 7: 128-135.

Mura, L.: Ključnikov, A.; Tvaronavičienė, M.; Androniceanu, A. 2017. Development Trends in Human Resource Management in Small and Medium Enterprises in the Visegrad Group, Acta Polytechnica Hungarica 14(7): 105-122 (http://www.uni-obuda.hu/journal/Issue 78.htm)

National Accounts of OECD Countries, Volume 2017 Issue 2: main aggregates. Gross domestic product, output and income approach. Access mode https://www.keepeek.com//Digital-Asset-Management/oecd/economics/national-accounts-of-oecd-countries-volume2017-issue-2_na_ma_dt-v2017-2-en\#page1

OECD Innovation and Knowledge-Intensive Service Activities. 2006. http://www.oecd.org/sti/inno/innovationandknowledge-intensiveserviceactivities.htm

OECD site. http://www.oecd-ilibrary.org/economics/national-accounts-of-oecd-countries_2221433x

Official website of the President of Kazakhstan. http://www.akorda.kz

Rostow U.U.1973. Policy and growth stages. 357 p.

Sarkar, S.; Coelho, D. M.; Maroco, J. 2016. Strategic Orientations, Dynamic Capabilities and Firm Performance: an Analysis for Knowledge Intensive Business Services, Journal of the Knowledge Economy 7(4): 1000-1020. http://dx.doi.org/10.1007/s13132-016-0415-3 
Schwab, K.; Porter, M.E.; Sachs, J.D. 2013. The Global Competitiveness Report 2011-2012. Executive Summary. N.Y.: Oxford University Press for the World Economic Forum p. 1-11.

Services in the modern economy. Resp. editors L.S. Demidova, V.B. Kondratiev. M., National Research Institute of World Economy and International Relations, 2010, 342 p.

Singelmann, J. 1978. The sectoral transformation of the labor force in the seven industrialized countries, 1920-1970, American Journal Sociology, 3: 23-26.

State program “Information Kazakhstan - 2020". http://egov.kz/cms/ru/articles/gp_inf_kaz_2020

State program of industrial-innovative development. http://www.akorda.kz/ru/official_documents/strategies_and_programs

Sulphey, M. M.; AlKahtani, N. S.; Syed,A. M. 2018. Relationship between admission grades and academic achievement, Entrepreneurship and Sustainability Issues 5(3): 648-658. https://doi.org/10.9770/jesi.2018.5.3(17)

Tachiciu L. 2016. Impact of knowledge intensive business services on economic performance of sectors and regions, Amfiteatru Economic 18(41): 5-6.

Toffler E. 2010. The third wave. M.: ACT 784 p.

Tvaronavičienė, M., Shishkin, A. 2017. Lifelong Learning as a Facet of Sustainable Economic Development 3 rd International Conference On Lifelong Education And Leadership For All ICLEL 2017 / September 12-14, 2017 / Polytechnic Institute of Porto, Porto - PORTUGAL, ISBN 978-605-66495-2-3 p. 1154 - 1160 http://www.ijlel.com/conferance17/139.pdf; https://www.iclel.com/iclel-17-conferencepr-book

USA: Opportunities and Limits of Economic and Political Leadership. In 2 vol./resp. editors F.G. Voitolovsky, E.V. Kirichenko. Vol.1 / Edited by E.V. Kirichenko. M.: National Research Institute of World Economy and International Relations, 2016, 240 p.

Vainstein, G. 2012. From new technologies to the "new economy", World economy and international relations, 10: 22-29

Varnavsky, V.G. 2016. Economic growth in the US: trends and factors, World economy and international relations 60(2): 26-39.

Zemlickiene, V.; Mačiulis, A.; Tvaronavičienè, M. 2017. Factors impacting the commercial potential of technologies: expert approach, Technological and Economic Development of Economy, 23(2): 410-427 http://dx.doi.org/10.3846/20294913.2016.1271061

Zenka, J.; Novotny, J.; Slach, O.; Ivan, I. 2017. Spatial Distribution of Knowledge-Intensive Business Services in a Small Post-Communist Economy, Journal of the Knowledge Economy 8(2): 385-406. http://dx.doi.org/10.1007/s13132-015-0260-9

Zhou, D.; Kautonen, M.; Wang, H. C.; Wang, L. 2017. How to interact with knowledge-intensive business services: A multiple case study of small and medium manufacturing enterprises in China, Journal of Management \& Organization 23(2): $297-318$.

\section{Elena PETRENKO}

ORCHID ID: 0000-0001-6892-2392

\section{Tatyana PRITVOROVA}

ORCHID ID: 0000-0002-6306-3960

\section{Baldyrgan DZHAZYKBAEBA}

ORCHID ID: 0000-0003-2851-5463 